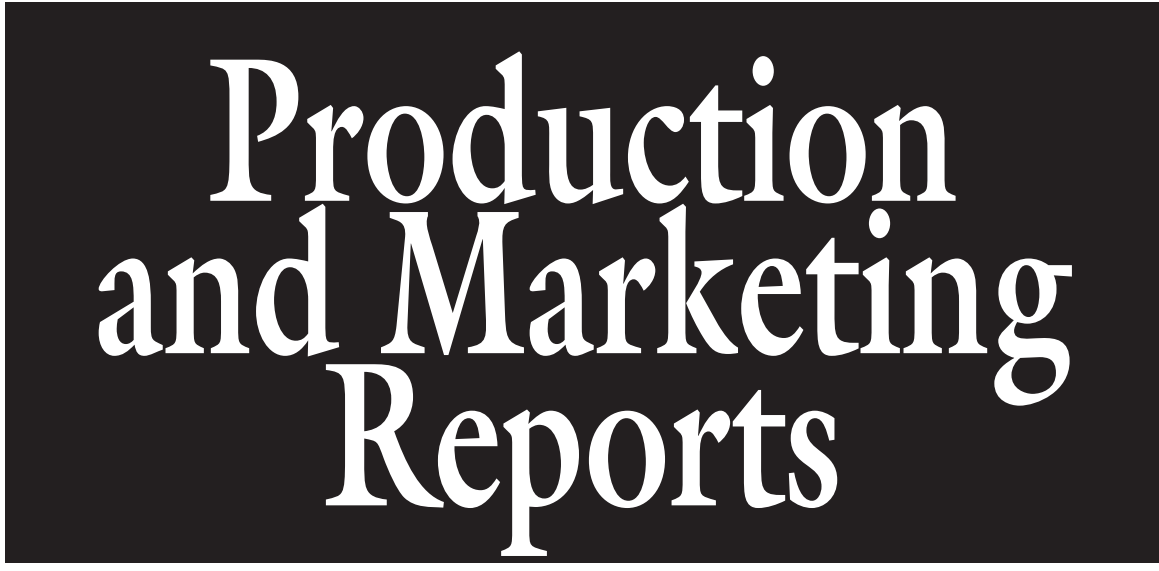

\section{Potential Economic Impact of Laurel Wilt Disease on the Florida Avocado Industry}

\author{
Edward A. Evans ${ }^{1}$, Jonathan Crane ${ }^{1,4}$, Alan Hodges ${ }^{2}$, \\ and Jason L. Osborne ${ }^{3}$
}

AdDITIONAL INDEX wORDs. Persea americana var. americana, $P$. americana var. guatemalensis, P. borbonia, P. palustris, Sassafras albidum, Mangifera indica, redbay ambrosia beetle, Xyleborus glabratus, Raffaelea lauricola, input-output model

\begin{abstract}
SuMmaRY. This article describes and provides preliminary estimates of the potential economic losses that could result from an incursion of the recently discovered exotic laurel wilt disease caused by Raffaelea lauricola, in the main avocado (Persea americana) growing area of Florida. Estimates are provided for the direct losses as well as the indirect or "spillover" losses that could occur across the rest of the regional economy. The Impact Analysis for Planning (IMPLAN) input-output multipliers were used in assessing the regional impacts. The results of the investigation indicate that the direct loss to the industry in terms of lost sales, property damage, and increased management costs could range from $\$ 356$ million in a do-nothing situation to about $\$ 183$ million if damage control measure were $50 \%$ effective. If increased management costs and decreased property values are ignored, the adverse impact on the regional economy could range from $\$ 54$ million in a do-nothing situation to $\$ 27$ million in a case in which the treatments result in only a $50 \%$ reduction in avocado production.
\end{abstract}

$\mathrm{T}$ he Florida avocado industry is the state's second-largest fruit industry (behind citrus) and is worth $\$ 12$ to $\$ 14$ million per year at the farm gate [U.S. Department of Agriculture (USDA), 2008a] and $\$ 30$ million at the wholesale end of

We are indebted to J.E. Peña and R.C. Ploetz at the University of Florida's Tropical Research and Education Center in Homestead for their laurel wilt disease research.

${ }^{1}$ University of Florida, Tropical Research and Education Center, 18905 SW 280th Street, Homestead, FL 33031

${ }^{2}$ University of Florida, Food and Resource Economics Department, University Avenue, Gainesville, FL 32611

${ }^{3}$ Miami-Dade County Extension Service, 18710 SW 288 Street, Homestead, FL 33030

${ }^{4}$ Corresponding author. E-mail: jhcr@ufl.edu. the market (P. Brooks, personal communication). About $85 \%$ of the crop is sold outside of the state; hence, the industry brings in a substantial amount of "new dollars" to the state, resulting in an overall economic impact of about $\$ 54$ million/year (authors' calculation; Degner et al., 2002). The industry consists of about 7400 acres, representing about $60 \%$ of the total tropical fruit crop acreage, and there are about 951 growers (USDA, 2008a, 2009; J.H. Crane, unpublished data), and 35 registered avocado handlers and shippers (P. Brooks, personal communication). Of these 7400 acres, over $98 \%$ are located in southwestern Miami-Dade County. The range in orchard size is from 0.1 to over 500 acres (USDA, 2009). However, $93 \%$ of the farms are 15 acres or less, and the most common farm size category is 1 to 5 acres. Most of these growers depend on proceeds from the sale of avocado to supplement their incomes, and many of the packing houses depend almost exclusively on the fruit to ensure that their operations remain financially viable. In several of the packing houses, the revenue from handling avocado accounts for between $60 \%$ and $80 \%$ of the total revenue and subsidizes the handling of other less common tropical fruits (C. Wheeling, personal communication). Moreover, avocado orchards provide many nonfood benefits, including the retention of open space/ landscaping, well-field recharge, recreation/relaxation, wildlife habitats, canopy cover, and carbon sequestration.

Florida grows primarily West Indian (Persea americana var. americana) and Guatemalan (P. americana var. guatemalensis)-West Indian hybrid avocado, which are smooth skinned and large (up to $40 \mathrm{oz}$ ), with less oil and fewer calories than the 'Hass' avocado produced in California, Chile, and Mexico (Crane et al., 2007).

In 2002, the redbay ambrosia beetle (Xyleborus glabratus), along with its fungal symbiont, the laurel wilt pathogen, was introduced through Port Wentworth, GA, on contaminated solid wood packing material (Fraedrich et al., 2008; Harrington et al., 2008). Within 2 to 3 years of the initial introduction, extensive mortality of native redbay (Persea borbonia) trees had occurred in Georgia and South Carolina. In 2005, humans spread the pest into

\begin{tabular}{llll}
\hline $\begin{array}{l}\text { Units } \\
\begin{array}{l}\text { To convert U.S. to SI, } \\
\text { multiply by }\end{array}\end{array}$ & U.S. unit & SI unit & $\begin{array}{l}\text { To convert SI to U.S., } \\
\text { multiply by }\end{array}$ \\
\hline 0.4047 & acre $(\mathrm{s})$ & $\mathrm{ha}$ & 2.4711 \\
0.0731 & $\mathrm{fl} \mathrm{oz} / \mathrm{acre}$ & $\mathrm{L} \cdot \mathrm{ha}^{-1}$ & 13.6840 \\
0.3048 & $\mathrm{ft}$ & $\mathrm{m}$ & 3.2808 \\
3.7854 & $\mathrm{gal}$ & $\mathrm{L}$ & 0.2642 \\
1.6093 & mile(s) & $\mathrm{km}$ & 0.6214
\end{tabular}


northern Florida, and by 2007, into central Florida (Reid et al., 2009). In 2007 , the first avocado tree to succumb to the pest occurred in a home landscape in Jacksonville, FL (Duval County). Testing in pest-infested areas and under greenhouse conditions confirmed avocado susceptibility to the redbay ambrosia beetle attack and damage or death from laurel wilt (Mayfield et al., 2008). The pest continues to move slowly southward 20 to 30 miles per year toward the main avocado production area through the native areas via native host plants such as redbay and swampbay (Persea palustris) and through the urban landscape via dooryard avocado trees (Crane et al., 2008; Koch and Smith, 2008). However, it could arrive much sooner if introduced inadvertently in contaminated host wood (e.g., redbay firewood, barbecue smoke-wood, etc.). Because the mortality from laurel wilt is so high $(>92 \%)$ and the discovery that avocado is attacked by the redbay ambrosia beetle, the continued existence of the Florida avocado industry is now being seriously threatened (Fraedrich et al., 2008; Mayfield, 2007).

The demise of the avocado industry in Florida could have catastrophic consequences for the surrounding regional and local economies. Besides direct losses to the state's avocado industry in terms of lost incomes and decreased property values, such an event would generate a chain reaction impacting sales, income, and employment in other related sectors. The purpose of this paper is to describe and provide preliminary estimates of the potential losses that could result from an incursion of this disease in the main avocado production area in Florida.

LAUREL WILT DISEASE: ECOLOGY, DAMAGE CAUSED, AND MANAGEMENT OF THE DISEASE. Laurel wilt is a vascular disease that causes extensive mortality of plants in the Laurel family (Lauraceae). There are numerous species within Lauraceae in Florida; examples include forest species such as redbay and sassafras (Sassafras albidum) and major commercial fruit crop species such as avocado (Mayfield et al., 2008). The laurel wilt pathogen is new to the United States and was first recognized on redbay trees on Hilton Head Island, SC, in 2002. Since then, the disease has spread to over 55 counties in Florida, Georgia, and South Carolina. In 2006, the disease was found as far south as Indian River County, FL, and has now spread to Okeechobee, Osceola, and St. Lucie counties in Florida (Reid et al., 2009).

The disease is vectored by the redbay ambrosia beetle. The adult female beetle carries the spores of the laurel wilt pathogen in special mouth pouches called mycangia and on its body (Fraedrich et al., 2008; Harrington et al., 2008). As the beetle bores into the wood, forming galleries, the spores on its body inoculate the tree, germinate, and grow, colonizing the outer wood (sapwood) of the host plant. The fungal hyphae block water and nutrient movement in the sapwood, resulting in eventual tree death (Crane et al., 2008). The entire process from the time the tree becomes infected with the fungus until death may occur in a matters of weeks to several months (R.C. Ploetz, personal communication).

At present, there are no registered fungicides for avocado that will control laurel wilt. While chemical and or biological control of the vector might be a possibility, not much research currently exists to implement the program before infestation (Koch and Smith, 2008). Chemical control of the beetle is complicated by the fact that adult beetles must be in the immediate area of aerial sprays to be controlled. Detection of adult beetles involves setting and monitoring traps and/or scouting orchards. Once the adult beetles bore into the trees, contact insecticides are ineffective (Crane et al., 2008). In the absence of any effective control treatments, growers are being advised to be vigilant for signs of the beetle. Limbs and branches of redbay ambrosia beetle infested trees in commercial orchards should be removed and burned. The initial (first one or two) trees that have died from an infestation should be cut and burned because chipping will not kill the developing larvae. Trees that are not destroyed by burning remain a source of new beetle infestations. However, tree destruction may not inhibit the spread of the beetle once established in an area nor be an economically viable solution to prevent further infestations. In addition, as a type of prophylactic treatment, growers have been advised to apply permethrin (Permethrin 3.2 AG; Arysta LifeScience North America, Cary, NC or Permethrin 3.2 EC; Helena Chemical, Collierville, TN) to the trunk and major limbs from the base of the tree up to about $10 \mathrm{ft}$ above the ground from March through December (Crane et al., 2008). However, the effectiveness of this treatment has not been tested.

\section{Materials and methods}

Quantifying the potential losses that could result from the establishment of the pest and disease involves estimating the direct losses to the avocado industry as well as the indirect or "spillover" losses that could occur across the rest of the regional economy. The direct losses include lost income, lower property values, and increased management costs, including the costs associated with surveillance, plant protection products, the loss/disposal of infected trees, and potentially replanting with tolerant or resistant avocado cultivar. Quantifying the secondary or indirect impacts is much more challenging and requires the use of an inputoutput (I-O) model such as Impact Analysis for Planning (IMPLAN) (Miller and Blair, 1985). Such a model describes the regional economy as represented by a set of I-O tables that capture the supply and demand of goods and services in the region, as well as the interdependencies among industries and the associated primary factors of production. For example, the avocado industry has a direct requirement for inputs such as chemicals, fertilizers, and packing materials from the manufacturing sector, as well as transportation services. These sectors, in turn, require energy inputs to process their products and transport goods. A decrease in the production of avocado reduces the demand for products and services, and labor, which consequently reduces incomes earned by households, thus creating an adverse ripple effect throughout the regional economy.

The total regional economic impacts were estimated using IMPLAN I-O multipliers, which capture the indirect and induced effects of sales outside Florida that bring new money into the region and generate further economic activity as these dollars circulate through the economy 
(Minnesota IMPLAN Group, 2007). Indirect effects represent the economic activity generated by businesses that furnish inputs to the agricultural and natural resource industries, while induced effects represent the impacts of industry employee household spending.

Because the ambrosia beetle and laurel wilt disease are recently identified pests and the exact effects of treatments cannot be known for certain, three scenarios were investigated based on the worse case estimates provided by scientists researching and managing the disease complex. the do-nothing scenario. The second considers the situation in which production loss equals $75 \%$, implying that the treatment would be only $25 \%$ effective. The third scenario describes production loss equaling $50 \%$.

\section{Results and discussion}

Direct cost estimates. The direct cost estimates are broken down into three categories: potential sale losses, decreased property values, and increased management costs.

Potential sale losses. As noted earlier, at the wholesale level of the marketing chain, the industry is worth about $\$ 30$ million. Given that in the worst-case scenario, the disease could destroy the entire industry, this value represents the maximum potential sales loss (Table 1). A $75 \%$ or $50 \%$ reduction in the crop could result in potential sale losses of $\$ 22.5$ million and \$15 million, respectively. Because it is felt that any such declines could adjustments were made for the expected decrease in the domestic production of avocados. Countries such as the Dominican Republic produce similar cultivars and could, within a short time, increase avocado exports to the United States. In addition, some consumers would likely switch The first scenario is the base case or easily be replaced by imports, no price

to another variety, namely 'Hass' avocado, which is the main variety produced in California and imported from Mexico and Chile. Not included in the estimates are anticipated declines in sales of nursery avocado plants (in the presence of the vector and disease, growers would be less likely to replace trees that are damaged or killed) or the lost value of noncommercial avocado production.

DeCline IN PROperty VAlue. Real estate is a major asset on the farm sector balance sheet, accounting for nearly $79 \%$ of the total U.S. farm assets in 2000 (USDA, 2008b). Several factors contribute to the market value of farmland, including speculation, land productivity, and the profitability (net income) of the commodity grown. Avocado production is one of the most profitable orchard crops grown in southern Florida. Evidence of this is the fact that more than one-half of the tropical fruit crop acreage is planted with avocado. A disease such as laurel wilt, in the absence of any effective treatment, would most likely result in decreased property values.

To assess the potential for a decline in property values, we estimated the value of an established orchard based on the estimated value of a mature avocado tree using the internet tool Tree Value Analysis (Evans et al., 2006). Using the tool and inserting a farm gate price of avocado of $\$ 0.45 / \mathrm{lb} \quad[2007$ average growers price (USDA, 2008c)] and the cost for stump removal of $\$ 150 /$ tree (Evans et al., 2006), we estimate the value of a mature tree to be around $\$ 500$. At an estimated value of $\$ 500$ for a mature tree and an assumed planting density of 87 trees/acre (C.F. Balerdi, personal communication), the additional value of an established avocado grove is assessed at $\$ 43,500 /$ acre. With the current market value for an avocado grove being

Table 1. Estimates of the direct economic loss associated with potential infestation of the redbay ambrosia beetle-laurel wilt pathogen of the avocado orchards in southern Florida.

\begin{tabular}{lccc}
\hline Item & Baseline $(\$)$ & $\begin{array}{c}\text { 75\% reduction in } \\
\text { production }(\$)\end{array}$ & $\begin{array}{c}\text { 50\% reduction in } \\
\text { production }(\$)\end{array}$ \\
\hline Industry sales loss (avocados) & $30,000,000$ & $22,500,000$ & $15,000,000$ \\
Decline in property value & $326,250,000$ & $244,688,000$ & $163,125,000$ \\
Increased management costs & - & $4,525,000$ & $4,525,000$ \\
Total value & $356,250,000$ & $271,713,000$ & $182,650,000$ \\
\hline
\end{tabular}

in the vicinity of $\$ 80,000 /$ acre, such a decline would represent a loss of about one-half of the market value. If the total bearing acreage of 7400 acres were to be destroyed, property values could plummet by about $\$ 326$ million (Table 1). In other words, growers could see their net worth (wealth) decreased by this amount, which could affect their willingness to continue producing avocado. This estimate does not include nonbearing or immature orchards, which most likely would also be affected if the disease were to become established.

INCREASED MANAGEMENT COSTS. Avocado production in southern Florida has not had any major insect pests threatening production. To date, the main threats faced by southern Florida growers have been damages caused by tropical storms and phytopthora (root rot due to flooding). Consequently, the amount spent on pest and disease management and cultural controls as an overall percentage of operating costs has been relatively small compared with other fruit crops such as mango (Mangifera indica) (C.F. Balerdi, personal communication). However, the situation could change with the imminent arrival of vectors and the associated pathogens.

As discussed earlier, currently there are no registered fungicides for avocado that will control laurel wilt disease. Moreover, control or eradication of the main vector, ambrosia beetle, is complicated due to its ability to bore into tree trunks and branches. Consequently, growers have been advised to adopt a prophylactic approach involving the periodic application of permethrin, which costs about \$105/ gal. Based on the recommended rate of application of about $8 \mathrm{fl} \mathrm{oz} /$ acre, the material cost per treatment is $\$ 6.50 /$ acre. Adding to this the application cost (labor and machinery) of $\$ 12 /$ acre, the total cost per application is estimated at $\$ 18.50 /$ acre. Given that, on average, 18 applications would be required per year, the production cost could be expected to increase by $\$ 333 /$ acre per year Assuming all the avocado acreage (7400) was treated at this rate, the total cost would increase by about $\$ 2.5$ million/year (Table 1). To this amount is added the sum of $\$ 2$ million, estimated as the additional cost that would be incurred, given the increased 
Table 2. The potential economic impacts of the redbay ambrosia beetle-laurel wilt pathogen on the regional economy of southern Florida.

\begin{tabular}{lccr}
\hline Item & $\begin{array}{c}\text { Scenario 1- base } \\
\text { case }\end{array}$ & $\begin{array}{c}\text { Scenario 2\% to 75\% } \\
\text { reduction in production }\end{array}$ & $\begin{array}{r}\text { Scenario 3\% to 50\% } \\
\text { reduction in production }\end{array}$ \\
\hline $\begin{array}{l}\text { Industry sales (\$ output) } \\
\text { Share of avocado production shipped }\end{array} \quad 30,000,000$ & $7,500,000$ & $15,000,000$ \\
$\quad$ outside the production area (\%) & 85 & 85 & 85 \\
Output impacts (\$) & $54,266,259$ & $13,566,565$ & $27,133,130$ \\
Employment impacts (no. jobs) & 546 & $4,918,568$ & 273 \\
Labor income impacts $(\$)$ & $19,674,272$ & 465,604 & $9,837,136$ \\
Indirect business tax impacts $(\$)$ & $1,862,415$ & & 931,208 \\
\hline
\end{tabular}

frequency of monitoring/scouting for the disease. In calculating the latter, it is assumed (based on the advice of industry experts and extension agents) that scouting would have to be conducted at least nine times per year, at an estimated total cost of $\$ 270 /$ acre. This estimate does not include the costs of burning infected branches and trees or the cost for insect trap and kill systems. Research is in progress with short-term and long-term strategies for control. These include chemical control of redbay ambrosia beetle and laurel wilt pathogen, development and use of repellents and trap and kill insect systems, and eventually biological control.

Secondary cost/economic IMPACT. I-O analysis is used to estimate the economic effects of the laurel wilt disease on the regional economy. Specifically, Table 2 shows the base line situation (Scenario 1) as well as the economic impacts resulting from a $75 \%$ (Scenario 2 ) and 50\% (Scenario 3 ) reduction in output, respectively. Only the direct sales losses (not the assessed decline in property values or increased management costs) are used in the analysis to reflect the changes in the value of avocado production. As shown in Table 2, under Scenario 2, a $75 \%$ reduction in avocado production would cause the direct sales output to fall from $\$ 30$ million to $\$ 7.5$ million (implying sales losses of $\$ 22.5$ million). The reduced sales output reduces the demand for inputs from other related sectors, such as the chemical, fertilizer, and transportation sectors (indirect impact), causing such sectors to cut back on their economic activity. As shown in Table 2, the consequence of such actions is that total sales (economic impact of all related sectors) would decline by $\$ 40.5$ million, from $\$ 54$ million to about $\$ 13.5$ million. The reduction in economic activity due to the reduction in avocado production, as well as in related input sectors, causes a reduction in the demand for labor. Table 2 shows that employment (in terms of fulltime equivalent) would decline from 546 to 136 employees. The reduction in the need for labor resources reduces the amount paid out, causing labor income to fall from \$19.7 million to under $\$ 5$ million. Government revenues in the form of indirect business tax would also be adversely affected, as the contraction of the regional economy due to reduced sales would cause indirect business taxes to fall from $\$ 1.9$ million to $\$ 0.5$ million, a decline of $73 \%$.

A similar situation would be observed under Scenario 3, except that the magnitude of the economic impact would be less severe but still substantial. Hence, under the latter, the total economic impact would decline from \$54 million to \$27.1.

\section{Conclusion}

Together, the ambrosia beetle and laurel wilt disease represent a serious threat to the Florida avocado industry. Currently, the industry generates an economic impact of over \$54 million, contributes to agricultural labor employment, and is a source of $\$ 1.9$ million annually in government revenue. Many of the local packing houses depend almost exclusively on this crop to sustain their operations. Moreover, the industry contributes several nonmarket benefits such as open space retention, canopy cover, carbon sequestration, and wildlife habitats.

Our economic analysis indicates that if laurel wilt disease were to become established in the main avocado industry, the direct loss to the industry in terms of lost sales, property damage, and increased management costs could range from $\$ 356$ million in a do-nothing situation to about $\$ 183$ million if damage control were $50 \%$ effective. If increased management costs and decreased property values are ignored, decreased economic activity (economic impact) could range from $\$ 54$ million in a do-nothing situation to $\$ 27$ million in a case in which the treatments result in only a $50 \%$ reduction in avocado production. Notwithstanding, the impact on the local economy would be catastrophic if this occurred because many of the packing houses would no longer be able to remain in business. Even if the packing houses that remain in operation became major redistributors for imported produce, this would not be enough to offset the losses to the local economy. Moreover, our assessment of the impacts can be considered as conservative because no attempts were made to quantify the economic impact on noncommercial production (residential infestations) avocado or forest trees, scenic beauty/esthetics, wildlife, and the loss of canopy cover.

In light of the magnitude of the impacts and potential losses associated with laurel wilt disease, it is imperative that efforts be made to implement policies that will decelerate the spread of the disease and to invest in research that could lead to the development of effective treatments and preserve the industry.

\section{Literature cited}

Crane, J.H., C.F. Balerdi, and I. Maguire. 2007. Avocado growing in the Florida home landscape. Hort. Sci. Dept., Florida Coop. Ext. Serv., Inst. Food Agr. Sci., Univ. Florida. Circular 1034.

Crane, J.H., J. Peña, and J.L. Osborne. 2008. Redbay ambrosia beetle-laurel wilt 
pathogen: A potential major problem for the Florida avocado industry. Hort. Sci. Dept., Florida Coop. Ext. Serv., Inst. Food Agr. Sci., Univ. Florida, HS1 136.

Degner, R.L., T.J. Stevens, and K.L. Morgan. 2002. Miami-Dade County Agricultural Land Retention Study, Appendix B, Economic Issues. Florida Agr. Mkt. Res. Ctr., Inst. Food Agr. Sci. Univ. Florida, Gainesville.

Evans, E., C. Balerdi, J. Crane, and S. Nalampang. 2006. Determining the value of an orchard tree. Food Resource Econ. Dept., Florida Coop. Ext. Service, Inst. Food Agr. Sci., Univ. Florida, Gainesville.

Fraedrich, S.W., T.C. Harrington, R.J. Rabaglia, M.D. Ulyshen, A.E. Ayfieldiii, J.L. Hanula, J.M. Eickwort, and D.R. Miller. 2008. A fungal symbiont of the redbay ambrosia beetle causes a lethal wilt in redbay and other Lauraceae in the southeastern United States. Plant Dis. 92:215-224.

Harrington, T.C., S.W. Fraedrich, and D.N. Aghayeva. 2008. Raffaelea lauricola, a new ambrosia beetle symbiont and pathogen on the Lauraceae. Mycotaxon 104:399-404.
Koch, F.H. and W.D. Smith. 2008. Spatiotemporal analysis of Xyleborus glabratus (Coleoptera: Circulionidae:Scolytinae) invasion in eastern U.S. forests. Environ. Entomol. 37:442-452.

Mayfield A.E., III. 2007. Laurel wilt: A serious threat to redbay and other related native species. Palmetto 24:8-11.

Mayfield A.E., III, J.E. Peña, J.H. Crane, J.A. Smith, C.L. Branch, E.D. Ottoson, and M. Hughes. 2008. Ability of the redbay ambrosia beetle (Coleoptera: Curculionidae: Scolytinae) to bore into young avocado (Lauraceae) plants and transmit the laurel wilt pathogen (Raffaelea sp.). Fla. Entomol. 91:485-487.

Miller, R.E. and P.D. Blair. 1985. Inputoutput analysis: Foundations and extensions. Prentice-Hall, Englewood Cliffs, NJ.

Minnesota IMPLAN Group. 2007. Implan (professional, economic impact analysis and social accounting software) and Florida state data package. Minnesota IMPLAN Group, Inc., Stillwater, MN.

Reid, L., B. Mayfield, and J. Johnson. 2009. Distribution of counties with laurel wilt disease symptoms by year of initial detection. 23 May 2009. <http://www. fs.fed.us/r8/foresthealth/laurelwilt/dist_ map.shtml>.

U.S. Department of Agriculture. 2008a. Noncitrus fruits and nuts: 2008 preliminary summary, Fr Nt 1-3 (09) a. 22 May 2009. <http://usda.mannlib.cornell. edu/usda/current/NoncFruiNu/Nonc FruiNu-01-23-2009_revision.pdf $>$.

U.S. Department of Agriculture. 2008b. Land use, value, and management: Agricultural land values. 20 Dec. 2008. <http://www.ers.usda.gov/Briefing/ landuse/aglandvaluechapter.htm $>$.

U.S. Department of Agriculture. 2008c. Fruit and tree nut yearbook spreadsheet files (89022). 2 Jan. 2009. <http://usda. mannlib.cornell.edu/usda/ers/89022/ Table-B09.xls>.

U.S. Department of Agriculture. 2009. 2007 Census of agriculture, Florida: State and county data, volume 1: Graphic area series, part 9. 10 Apr. 2009. <http://www. agcensus.usda.gov/Publications/2007/ Full_Report/Volume_1,_Chapter_1_ State_Level/Florida/flvl.pdf $>$. 